\title{
Pengaruh Kematangan Emosi terhadap Sikap Tasamuh
}

\author{
Aris Sofyan \\ SMA N 2 Ungaran, Kabupaten Semarang \\ Email: Aris123@gmail.com
}

\begin{abstract}
Abstrak
Penelitian ini berusaha untuk mengetahui pengaruh kematangan emosi terhadap sikap tasamuh dari mahasiswa semester delapan Pendidikan Agama Islam STAIN Salatiga pada tahun akademik 2013/2014. Penelitian ini ingin menjawab: 1) Bagaimana kematangan emosi siswa; 2) Bagaimana sikap dari tasamuh siswa; 3) Apakah ada pengaruh pada sikap tasamuh menuju kedewasaan emosional dari siswa. Penelitian ini menggunakan metode kuantitatif dengan populasi 45 responden. Data $\mathrm{X}$ dan Y dikumpulkan dengan menggunakan kuesioner. Hasil penelitian menunjukkan: 1) Kematangan emosi mahasiswa tergolong sedang dengan prosentase $(53,33 \%)$; 2) Sikap tasamuh siswa dengan persentase yang relatif tinggi $(48,89 \%)$. Data dianalisis menggunakan korelasi product moment. nilai R-xy diperoleh 0,528 lebih besar dari nilai r-tabel dengan tingkat signifikansi 5\% dari 0,294. Sementara di tingkat signifikansi $1 \%$, r-hitung adalah 0,380. Dari hasil tersebut terlihat bahwa r-hitung lebih besar dari r-tabel maka Ha diterima, sehingga hasil 0,528 adalah signifikan. Dapat disimpulkan bahwa hipotesis; 3) "Ada pengaruh
\end{abstract}


Mudarrisa: Jurnal Kajian Pendidikan Islam, Vol. 7, No. 1, Juni 2015: 59-88

kematangan emosi terhadap sikap tasamuh siswa" diterima berdasarkan analisis uji.

This study sought to determine the effect of emotional maturity toward the attitudes of tasamuh of eight semester Islamic Religious Education students of STAIN Salatiga in the academic year 2013/2014. This research wants to answer: 1) How is the emotional maturity of the students; 2) What is the attitude of tasamuh of the students; 3) Is there any influence on the attitudes of tasamuh toward emotional maturity of the students. This study uses quantitative methods. The population is 45 respondents. The data $X$ and $Y$ are collected using questionnaires. The results showed: 1) Emotional maturity of the students are classified as moderate by percentage (53.33\%); 2) The attitude of tasamuh of the students with relatively high percentage (48.89\%). The data is analyzed using product moment correlation. $R$-xy values obtained 0.528 greater than the value of r-table with significance level 5\% of 0.294. While in significance level 1\%, r-count is 0.380 . From the results it appears that $r$-count larger than r-table so Ha is received, thus the results of .528 is significant. It can be concluded that the hypothesis; 3) "There is the influence of emotional maturity toward attitude of tasamuh of the students" are accepted based on test analysis.

Kata kunci: emosi, tasamuh, mahasiswa

\section{Pendahuluan}

Psikologi merupakan ilmu yang mempelajari tentang banyak hal yang berhubungan dengan jiwa manusia diantaranya perasaan manusia, perilaku manusia, kebiasaan-kebiasaan yang dilakukannya termasuk emosi adalah salah satunya. Dalam ilmu psikologi, emosi merupakan kajian penting yang perlu dibahas karena dalam kehidupan sehari-hari manusia selalu tak lepas akan adanya gejala-gejala emosi yang timbul. Berbagai peristiwa yang sering terjadi yakni ketika manusia tidak lagi mendapatkan sesuatu yang diinginkan, mendapatkan sebuah masalah, 
cobaan datang terus menerus. Inilah yang menjadikan manusia kadangkadang meluapkan emosinya karena tidak dapat mengontrol atau mengendalikan dirinya sendiri terhadap keadaan yang dialaminya.

Selain itu emosi pada hakikatnya tidaklah mempelajari gejala negatif perasaan seorang manusia yang timbul namun juga mempelajari emosi manusia yang bersifat positif seperti bahagia, senang, dan ceria. Emosi tidak terjadi kadang-kadang namun emosi terjadi setiap hari dimana manusia akan memunculkan hal tersebut sesuai dengan kondisi yang dialaminya. Dengan berjalannya waktu, maka emosi akan selalu mengalami dinamika atau perubahan. Sehingga emosi mengalami perkembangan sesuai bergantinya kondisi dan usia manusia. Dimana kita perlu mempelajari tahapan emosi pada fase dasar hingga dewasa serta mengkajinya secara jelas dan ilmiah.

Emosi adalah kemampuan untuk memahami perasaan diri masing-masing dan perasaan orang lain, kemampuan untuk memotivasi diri sendiri dan menata dengan baik emosi-emosi yang muncul dalam diri sendiri maupun dalam berhubungan dengan orang lain, selain itu emosi memiliki kesadaran diri (Self Awareness), pengaturan diri (Self Regulation), motivasi (Motivation), Empati (Empathy) dan ketrampilan sosial (Social Skill) (Kawatja, 1982: 140).

Diketahui bahwa sifat perasaan emosi telah timbul selama masa bayi, bahkan sebagian ahli berpendapat bahwa masa bayi di dalam kandungannya pun sudah di pengaruhi oleh emosi. Akan tetapi, kita sendiri sering sekali kurang mengerti apakah tanda-tanda seperti menangis, tertawa, dan lain-lain masa awal bayi disertai atau diikuti 
dengan intensitas perasaan atau tidak. Menurut Bridges, emosi anak akan berkembang melalui pengalaman, sekalipun masih dangkal dan berubahubah. Ketika emosi bayi diungkapkan dalam bentuk marah dan takut dengan menangis atau gemetar.

Ketika bayi sudah berusia 8 bulan, ia mulai dapat memperlihatkan dengan sangat berbeda antara rasa marah dan takut. Selama pertumbuhan, perubahan pada ekspresi emosi itu semakin lama akan semakin jelas dan berbeda. Sebagai contoh, bayi akan menyerang benda-benda disekitar untuk mengekspresikan kemarahannya, lambat laun ia mampu memusatkan ekspresi emosinya langsung kepada objek yang menimbulkan kemarahannya (Djaali, 2013: 39).

Makin besar anak itu, makin besar kemampuan untuk belajar sehingga perkembangan emosi makin rumit. Perkembangan emosi melalui proses kematangan hanya terjadi sampai usia satu tahun maksudnya pada usia satu tahun bayi mengalami proses kematangan emosi melalui menangis, dan tertawa. Setelah itu perkembangan selanjutnya lebih banyak ditentukan oleh proses belajar (Hartati, 2005: 100).

Perkembangan emosi pada masa pertumbuhan anak semakin halus dalam mengekspresikannya sampai masa remaja. Peralihan ekspresi emosi yang tadinya kasar, karena terpengaruh latihan dan kontrol, berangsur-angsur tingkah laku emosionalnya berubah. Misalnya anak yang tadinya menjerit-jerit karena senang, pada saat remaja ia akan memperhalus ekspresinya. 
Pada akhirnya dia akan mencapai kemampuan tingkah lakunya sehubungan dengan apa yang terjadi pada dirinya. Semakin dewasa akan semakin dapat mengungkapkan dengan emosinya, karena emosinya menjadi semakin mudah diklasifikasikan seperti rasa takut, muak, dan benci, juga apresiasinya terhadap nilai, keinginan, cita-cita, minat dan reaksinya terhadap orang, lembaga, tanggung jawab, sudut pandang, dan gagasan orang lain (Djaali, 2013: 40).

Emosi timbul dari rangsangan (stimulus), stimulus yang sama mungkin dapat menimbulkan emosi yang berbeda-beda dan kadang arah berlawanan. Adapun rangsangan dapat muncul dari dorongan, keinginan atau minat yang terhalang, baik disebabkan oleh tidak atau kurangnya kemampuan individu untuk memenuhinya atau menyenangkan. Apabila semua keinginan dan minat tidak terhalang, dapat dikatakan bahwa secara emosional individu tersebut dalam keadaan stabil.

Kematangan menurut Rebert \& Rebert (2010: 555) diambil dari bahasa latin "maturus" yang artinya masak kondisi yang dewasa, pertumbuhan yang lengkap, pefungsian yang menyeluruh dan penuh. Kematangan dalam kamus lengkap psikologi, Chaplin (2008: 291), menjelaskan bahwa kematangan adalah keadaan telah mencapai suatu bentuk kematangan atau bentuk kedewasaaan.

Crow dan Crow, dalam Djaali (2013: 37), emosi adalah pengalaman yang efektif yang disertai oleh penyesuaian batin secara menyeluruh, di mana keadaan mental dan fisiologis sedang dalam kondisi meluap-luap, juga dapat diperlihatkan dengan tingkah laku yang jelas dan nyata. Kaplan dan Sanddok dalam Djaali (2013: 37), emosi adalah 
keadaan perasaan komplek yang mengandung komponen kejiwaan, badan, dan perilaku yang berkaitan dengan affect (ekspresi) dan mood ( perasaan).

Goleman, emosi adalah perasaan dan pikiran khasnya; suatu keadaan biologis dan psikologis; suatu rentangan dari kecenderungan bertindak. Menurut Kamus The American College Dictionary, emosi adalah suatu keadaan afektif yang disadari di mana dialami perasaan seperti kegembiraan (joy), kesedihan, takut, benci, dan cinta (dibedakan dari keadaan kognitif dan keinginan yang disadari; dan juga perasaan seperti kegembiraan (joy), kesedihan, takut, benci, dan cinta. (Djaali, 2013: 37).

Menurut Sarlito Wirawan Sarwono dalam Yusuf (2010: 115), berpendapat bahwa emosi merupakan setiap keadaan pada diri seseorang yang disertai warna afektif baik pada tingkat lemah (dangkal) maupun pada tingkat yang luas (mendalam).

Chaplin dalam Kartini Kartono (2008: 165), mendifinisikan emotion maturity/ kematangan emosi sebagai suatu keadaan atau kondisi mencapai tingkat kedewasaan perkembangan emosi; dan karena itu pribadi yang bersangkutan tidak lagi menampilkan pola emosi yang pantas bagi anak-anak. Istilah kematangan atau kedewasaan sering kali membawa implikasi adanya kontrol emosi. Bagian terbesar orang dewasa mengalami pula emosi yang sama dengan anak-anak, namun mereka mampu mengontrolnya lebih baik, khususnya di tengah-tengah situasi sosial. 
Hurlock (2006: 212), mengatakan bahwa laki-laki dan perempuan dikatakan sudah mencapai kematangan emosinya bila tidak lagi "meledakkan" emosinya di hadapan orang lain melainkan menunggu saat dan tepat yang lebih tepat untuk mengungkapkan emosinya dengan cara-cara yang lebih dapat diterima. Petunjuk kematangan emosi yang lain adalah bahwa individu menilai situasi secara kritis terlebih dulu sebelum bereaksi secara emosi, tidak lagi bereaksi tanpa berpikir sebelumnya seperti anak-anak atau orang yang tidak matang. Dengan demikian, remaja mengabaikan banyak rangsangan yang tadinya dapat menimbulkan ledakan emosi. Akhirnya, individu yang emosinya matang memberikan reaksi emosi yang stabil, tidak berubah-ubah dari satu emosi atau suasana hati kesuasana hati yang lain seperti dalam periode sebelumnya.

Untuk mencapai kematangan emosi, individu harus belajar memperoleh gambaran tentang situasi-situasi yang dapat menimbulkan reaksi emosi. Adapun caranya adalah dengan membicarakan berbagai masalah pribadinya dengan orang lain dan juga harus belajar menggunakan katarsis emosi untuk menyalurkan emosinya. Adapun cara yang dapat dilakukan adalah latihan fisik yang berat bermain atau bekerja, tertawa atau menangis (Hurlock, 2006: 213).

Dari pendapat para ahli diatas dapat ditarik kesimpulan bahwa kematangan emosi adalah kemampuan seorang individu untuk menggunakan emosinya secara baik, yang ditandai dengan pengontrolan diri, pemahaman seberapa jauh baik buruk dan apakah bermanfaat bagi dirinya dalam setiap tindakan maupun perbuatannya atau keadaan 
seseorang telah mencapai keadaan kedewasaan dari perkembangan emosionalnya sehingga dapat memberikan tanggapan emosionalnya secara kritis dan matang sesuai dengan tingkat usia dan tingkat masyarakatnya.

Intensitas dan lamanya respons emosional sangat ditentukan oleh kondisi fisik dan mental dari individu itu sendiri, juga faktor lain yang sangat menentukan adalah stimulus itu sendiri. Dapat dikatakan bahwa emosi akan berlangsung terus-menerus selama stimulan ada dan yang menyertainya masih aktif. Karena emosi mempengaruhi tingkah laku, tingkah laku akan terus terpengaruh selama stimulusnya aktif, namun demikian emosi bukan satu-satunya faktor yang menentukan tingkah laku.

Perubahan fisik dan fisiologis dapat dipengaruhi oleh rangsangan yang menimbulkan emosi. Emosi ini akan menghasilkan berbagai perubahan yang mendalam (visceral changes) dan akan mempengaruhi urat-urat kerangka di dalam tubuhnya. Jenis perubahan secara fisik dapat dengan mudah kita amati pada diri seseorang selama tingkah lakunya dipengaruhi emosi, misalnya dalam keadaan marah, cemburu, bingung, dan lain-lain. Hal inilah yang biasanya disebut kerangka individu. Adapun secara fisiologis perubahan yang terjadi tidak tampak dari luar, biasanya dapat diketahui melalui pemeriksaan atau tes diagnosis dari para ahli ilmu jiwa. Perubahan fisiologis pada saat emosi umumnya meliputi fungsi pencernaan, aliran darah, dan pengurangan air liur ( mulut terasa kering ), pengeluaran kelenjar endokrin, dan lain-lain (Djaali, 2013:38). 
Kemunculan emosi seseorang bisa dikenali dari ekspresi yang ditampilkan seketika itu, baik dari perubahan wajah, nada suara atau tingkah lakunya. Ekspresi emosi tersebut muncul dan sering kali sulit dikontrol atau ditutup-tutupi. Banyak orang secara spontan berteriak histeris lantaran terkejut, sementara yang lain memegang dada, atau tampak lemas dengan raut muka pucat pasi. Ada orang-orang tertentu yang bergetar anggota badannya (tremor) ketika marah, sementara yang lain dengan, mata melotot, wajah memerah, menjadi gagap seketika, atau ekspresi lain dalam bentuk tingkah laku seperti menggebrak meja, membenturkan kepala menggigit ujung jari-jemarinya.

Ekspresi emosi selain diwarisi secara genetik juga diperkaya oleh berbagai pengalaman dalam berinteraksi dengan orang lain. Berkacak pinggang di saat marah, menutup telinga ketika takut pada kilat dan halilintar, loncat kegirangan sewaktu memenangkan pertandingan atau lari menghadap penonton sehabis menyerangkan bola kegawang lawan dalam pertandingan sepak bola, adalah contoh-contoh ekspresi emosi dalam bentuk tingkah laku yang diperoleh dari pengalaman berinteraksi dengan orang lain. Bentuk-bentuk ekspresi emosi manusia yang sering muncul dalam realitas: ekspresi wajah, suara, sikap dan tingkah laku, serta ekspresi lain seperti pingsan, kejang-kejang, ngompol, dan sebagainya (Hude, 2006:47).

Menurut Crow \& Crow dalam Djaali (2013:37), emosi adalah pengalaman yang afektif yang disertai oleh penyesuaian batin secara menyeluruh, di mana keadaan mental dan fisiologi sedang dalam kondisi yang meluap-luap, juga dapat diperlihatkan dengan tingkah laku yang 
jelas dan nyata. Menurut Kaplan dan Saddock, emosi adalah keadaan perasaan yang sangat kopleks yang mengandung komponen kejiwaan, badan, dan perilaku yang berkaitan dengan affect dan mood. Affect merupakan ekspresi sebagai tampak oleh orang lain dan affect dapat bervariasi sebagai respon terhadap perubahan emosi, sedangkan mood adalah suatu perasaan yang meluas, meresap dan terus menerus yang secara subjektif dialami dan dikatakan oleh individu dan juga dilihat oleh orang lain. Menurut Goleman, emosi adalah perasaan dan pikiran khasnya; suatu keadaan biologis dan psikologis; suatu rentangan dari kecenderungan untuk bertindak. Menurut kamus The American College Dictionary, emosi adalah suatu keadaan afektif yang disadari di mana dialami perasaan kegembiraan (joy), kesedihan, takut, benci, dan cinta (Djaali, 2013:37).

Emosi yang Allah berikan kepada manusia memiliki berbagai manfaat bagi kelangsungan hidup. Kegunaan emosi dapat dirasakan jika masih dalam batas-batas kewajaran. Di luar itu, dampaknya akan menggangu kehidupan manusia sendiri. Tanpa emosi, hidup menjadi hampa tidak berarti karena manusia tidak akan bisa merasakan lapangnya kebahagiaan dan sempitnya kesedihan (Mustofa, 2007: 15).

Anak laki-laki dan perempuan dikatakan sudah mencapai kematangan emosinya bila tidak lagi "meledakkan" emosinya dihadapan orang lain melainkan menunggu saat dan tepat yang lebih tepat untuk mengungkapkan emosinya dengan cara-cara yang lebih dapat diterima. Petunjuk kematangan emosi yang lain adalah bahwa individu menilai situasi secara kritis terlebih dulu sebelum bereaksi secara emosional, 
tidak lagi bereaksi tanpa berpikir sebelumnya seperti anak-anak atau orang yang tidak matang. Dengan demikian, remaja mengabaikan banyak rangsangan yang tadinya dapat menimbulkan ledakan emosi. Akhirnya, individu yang emosinya matang memberikan reaksi emosiaonal yang stabil, tidak berubah-ubah dari satu emosi atau suasana hati ke suasana hati yang lain, seperti dalam periode sebelumnya (Hurlock, 2006: 212).

Untuk mencapai kematangan emosi, remaja harus belajar memperoleh gambaran tentang situasi yang dapat menimbulkan emosi. Adapun caranya adalah dengan membicarakan berbagai masalah pribadinya dengan orang lain. Keterbukaan, perasaan dan masalah yang dipengaruhi sebagian oleh rasa aman dalam hubungan sosial.

Bila remaja ingin mencapai kematangan emosi, ia juga harus belajar menggunakan katarsis emosi untuk menyalurkan emosinya. Adapun cara yang dapat dilakukan adalah latihan fisik yang berat, bermain atau bekerja, tertawa atau menangis. Meskipun cara-cara ini dapat Menyalurkan emosi yang timbul karena usaha pengendalian ungkapan emosi, namun sikap sosial terhadap perilaku menangis adalah kurang baik dibandingkan dengan sikap sosial terhadap perilaku tertawa, kecuali bila tertawa hanya dilakukan bilamana memperoleh dukungan sosial (Hurlock, 2006: 213).

Sikap adalah faktor penentu untuk tingkah laku. Sikap merupakan kecenderungan untuk bertindak dengan cara-cara yang sangat khas pada saat menerima stimulasi tertentu. Sudah sering kita mendengar ada orang dewasa yang bertindak kekanak-kanakan. Hal ini dapat berarti individu itu tidak dapat menyesuaikan tingkah laku emosionalnya dengan tingkat 
kematangannya. Ketidak matangan emosional dapat ditunjukan melalui pola-pola respons yang beraneka ragam, yaitu dengan cara menarik perhatian, ucapan yang dibuat-buat, penampilan yang aneh, rasionalisasi (memberikan alasan yang tampaknya bagus terhadap tingkah lakunya yang tolol dan tidak diinginkan oleh orang lain), proyeksi (melemparkan kesalahan kepada orang lain atas kekurangan dan kelemahan sendiri), serta mimpi di siang hari bolong (menolak kenyataan).

Reaksi pemuasan seseorang dalam bentuk lain meliputi tingkah laku marah, identifikasi diri terhadap seorang pahlawan atau tokoh, mengeluarkan kecaman yang tidak layak kepada orang lain, dan memperlihatkan rasa cemburu (Djaali, 2013: 47).

Pada umumnya tingkah laku yang dimiliki oleh orang-orang jenis ini tidak konsisten. Individu yang sudah dapat mengatasi tingkah laku emosional diatas, biasanya adalah pria atau wanita yang sudah dapat menyesuaikan diri dengan baik, dan oleh masyarakat biasanya sudah dianggap sudah kompeten. Umumnya orang jenis ini pada siang hari diisi dengan kegiatan konstruktif, dan malam hari waktu mereka diisi dengan istirahat yang cukup. Dengan kegiatan yang teratur seperti ini, diharapkan kondisi emosionalnya akan menjadi lebih matang (Djaali, 2013: 48).

Manusia sebagai makhluk sosial senantiasa memerlukan orang lain dalam memenuhi kebutuhan-kebutuhannya, baik yang bersifat biologis maupun sosiogenis (perilaku sosial). Manusia tak mungkin mengisolasi diri sepenuhnya tanpa kontak dengan orang lain. Apalagi dunia saat ini kian sempit akibat cengkeraman globalisasi. Arus informasi bergerak sangat cepat tak terkendali dan memungkinkan orang 
mengetahui aneka peristiwa yang terjadi di berbagai belahan dunia saat itu juga.

Perkenalan antar etnis, sebagaimana pada interaksi personal antar sesama dalam berbagai lini kehidupan, baik antar individu dengan individu, individu dengan kelompok, maupun kelompok dengan kelompok. Dalam pelaksanaan interaksi itu, bahwa manusia di bumi ini beranak pinak dari suatu keluarga berkembang menjadi suku bangsa kemudian menjadi kelompok ras. Suku bangsa dan kelompok ras bisa memiliki perbedaan-perbedaan dari segi warna kulit, postur tubuh, bahasa, budaya, penampilan, golongan, status sosial dan sebagainya. Perbedaan-perbedaan ini tentu tidak menjadi penghalang untuk saling bahu-membahu menciptakan sikap toleransi, saling menghargai dan menghormati. Berbuat kebaikan adalah tugas dan tanggung jawab semua manusia, baik tua maupun muda, kaya maupun miskin, laki- laki maupun perempuan. Allah tidak pernah berlaku diskriminatif terhadap makhluknya karena perbedaan-perbedaan yang dimilikinya.

Kelompok mahasiswa terdiri dari pemuda dan pemudi dari sekitar umur 18 sampai 30 tahun dengan mayoritas kelompok umur sekitar 18 sampai 25. Masa umur antara 18 sampai 25 inilah masa usia mahasiswa yang sebenarnya. Mereka dapat digolongkan pada masa remaja akhir sampai masa dewasa awal atau dewasa madya. Dewasa muda merupakan tahap perkembangan yang paling dinamis sepanjang rentang kehidupan manusia, sebab seorang mengalami banyak perubahan-perubahan progresif secara fisik, kognitif maupun psikososio-emosional, untuk menuju integritas kepribadian yang semakin matang dan bijaksana. 
Sebagai seorang individu yang sudah tergolong dewasa, peran dan tanggung jawabnya tentu semakin besar. Ia tak lagi harus bergantung secara ekonomis, sosiologis ataupun psikologis pada orang tuanya. Mereka justru tertantang untuk membuktikan dirinya sebagai seorang pribadi yang dewasa mandiri. Segala urusan dan masalah yang dialami dalam hidupnya sedapat mungkin akan ditangani sendiri tanpa bantuan orang lain, termasuk orang tua. Berbagai pengalaman yang baik maupun yang gagal dalam menghadapi suatu masalah akan dapat dijadikan pelajaran yang berharga guna membentuk seorang pribadi yang matang, tangguh, dan bertanggung jawab terhadap masa depannya (Dariyo, 2003: $3)$.

Dilihat dari segi perkembangan pada usia mahasiswa ini merupakan pemantapan pendirian hidup atau identitas diri. Dengan kata lain, pemantapan itu dimasudkan pengujian lebih lanjut tentang pendirian hidup serta penyiapan diri dengan keterampilan dan kemampuan yang diperlukan untuk merealisasikan pendirian hidup yang telah dipilihnya. Pada masa remaja akhir, yang bersamaan dengan tahun-tahun pertama sebagai mahasiswa jika individu yang bersangkutan masuk perguruan tinggi, proses pematangan biologis-fisiologis makin melambat dan akhirnya mencapai taraf kematangan. Taraf ini biasanya dianggap telah tercapai dengan berakhirnya pertambahan tinggi badan, yang terjadi sekitar umur 20 atau 21 tahun. Bersamaan dengan itu problem-problem yang berkaitan dengan fisiologis-biologis juga menghilang dan penemuan pendirian hidup atau identitas diri makin mantap (Ahmadi \& Sholeh, 2005: 45). 
Menurut bahasa tasamuh berarti toleransi atau tenggang rasa, sedangkan menurut istilah tasamuh adalah sifat dan sikap tenggang rasa atau saling menghargai antar sesame manusia, walaupun pendirian atau pendapatnya berbeda (bertentangan) dengan pendiriannya sendiri. Sebagai makhluk sosial, manusia tidak akan pernah bisa untuk tidak membutuhkan orang lain, semua manusia tentu saling membutuhkan. Oleh karena itu antara satu manusia dengan manusia yang lainnya harus saling memperhatikan dan saling tolong menolong dalam kebajikan dan dalam berbagai aspek kehidupan, mulai dari aspek sosial, ekonomi, budaya, kemasyarakatan dan aspek kehidupan kemanusiaan lainya. Kehidupan yang damai akan tercipta apabila semua manusia menerapkan sikap tasamuh. bentuk dari tasamuh yaitu tasamuh sesama muslim dan non muslim. Tasamuh kepada muslim dan non muslim jelas diwajibkan, meskipun kepada yang berbeda agama bukan berarti harus bersaing tetapi bertasamuhlah supaya kehidupan menjadi tentram. Hikmah dari sikap tasamuh adalah menghilangkan perselisihan yang diakibatkan dari pemikiran negatif kepada orang lain, karena orang yang memiliki sikap tasamuh akan memiliki kepedulian sosial yang tinggi, akan selalu membantu orang yang memerlukan pertolongan, dan menumbuhkan cinta dan rasa kasih sayang sesama makhluk Allah.

Dalam hubungan interpersonal, prinsip kesetaraan dan bersikap tasamuh atau toleransi harus menjadi prinsip dasar, sehingga tidak seorang pun boleh berbuat zalim atau merendahkan orang lain dan suatu kelompok organisasi antar mahasiswa. Makna tasamuh adalah sabar menghadapi keyakinan-keyakinan orang lain, pendapat-pendapat mereka 
dan amal-amal mereka walaupun bertentangan dengan keyakinan dan batil menurut pandangan, dan tidak boleh menyerang dan mencela dengan celaan yang membuat orang tersebut sakit dan tersiksa perasaannya. Asas ini terkandung dalam banyak ayat al-Qur'an diantaranya:

"Dan janganlah kalian mencela orang-orang yang berdo'a kepada selain Allah, yang menyebabkan mereka mencela Allah dengan permusuhan dengan tanpa ilmu. Demikianlah Kami menghiasi untuk setiap umat amalan mereka, lalu Dia mengabarkan kepada apa yang mereka lakukan”. (Qs. alAn'am:108)

Dengan kesadaran terhadap prinsip itu, banyak hal yang pada awalnya dapat memicu emosi-emosi negatif seperti marah, benci, atau dendam dapat direduksi atau diredam hingga titik terendah. Dan sebaliknya, emosi-emosi positif yang selalu dicari manusia bisa diraih. Dalam banyak hal, emosi marah, benci, atau kecewa sering kali diawali oleh perlakuan tidak saling menghargai dan menghormati seperti yang tertuang dalam Qs. al-Hujarat: 13 sebagai berikut:

"Hai manusia, Sesungguhnya Kami menciptakan kamu dari seorang laki-laki dan seorang perempuan dan menjadikan kamu berbangsa-bangsa dan bersuku-suku supaya kamu saling kenalmengenal. Sesungguhnya orang yang paling mulia diantara kamu disisi Allah ialah orang yang paling taqwa diantara kamu. Sesungguhnya Allah Maha mengetahui lagi Maha mengenal" (Qs.al-Hujurat:13).

Setiap manusia diberikan akal, pikiran, dan perasaan dalam hidup bermasyarakat, perasaan harus mendapat perhatian oleh masing-masing anggota masyarakat. Salah satu bentuk perhatian terhadap perasaan 
sesama manusia ialah memiliki sikap tasamuh. Dengan demikian sikap tasamuh sangat diperlukan dalam kehidupan berteman dan bermasyarakat. Bersikap tasamuh berarti memberikan kesempatan kepada orang lain untuk mengambil haknya sebagaimana mestinya. Sikap tasamuh penting untuk diterapkan dalam kehidupan bermasyarakat dan beragama, untuk menciptakan persatuan dan kerukunan dengan sesama makhluk ciptaan Allah SWT.

Dari hal tersebut di atas, penulis dapat merumuskan beberapa masalah dalam penelitian ini sebagai berikut: Bagaimana Kematangan Emosi Mahasiswa STAIN Salatiga Program Studi Pendidikan Agama Islam Semester 8 Tahun Akademik 2013/2014, bagaimana Sikap Tasamuh Mahasiswa STAIN Salatiga Program Studi Pendidikan Agama Islam Semester 8 Tahun Akademik 2013/2014, dan adakah Pengaruh Kematangan Emosi Terhadap Sikap Tasamuh Mahasiswa STAIN Salatiga Program Studi Pendidikan Agama Islam semester 8 Tahun Akademik 2013/2014.

\section{Metode Penelitian}

Jenis penelitian yang dipakai penulis dalam penelitian ini adalah penelitian lapangan (Field Research) yaitu research yang dilakukan dikancah atau medan terjadinya gejala-gejala (Hadi, 2000: 9). Pada umumnya penelitian kuantitatif banyak dituntut menggunakan angka, mulai dari pengumpulan data, penafsiran terhadap data tersebut, serta penampilan dari datanya (Arikunto, 2006: 10). Dengan pendekatan deskriptif kuantitatif dengan statistik parametik. Pendekatan deskriptif 
kuantitatif adalah menggambarkan keadaan atau status fenomena (Hadi, 2000: 101). Dipilihnya pendekatan kuantitatif dalam penelitian ini dengan alasan untuk menguji keterkaitan antar variabel, yaitu antara variabel kematangan emosi dengan sikap tasamuh mahasiswa STAIN Salatiga program studi Pendidikan Agama Islam tahun akademik 2013/2014. Karena jenis penelitian ini adalah field research, maka dalam mengambil dan mengumpulkan data digunakan metode sebagai berikut: Metode Observasi Adalah pemgamatan dan pendataan secara sistematis terhadap fenomena yang diselidiki. Instrument observasi ini sebagai cross check terhadap questioner responden (Hadi, 2002: 136). Adapun bentuknya adalah observasi berisi data sistematis yakni pedoman observasi berisi daftar jenis kegiatan yang mungkin timbul dan akan diamati. Metode Interview (wawancara) Yaitu sebuah dialog yang dilakukan pewawancara untuk memperoleh informasi dari wawancara (Arikunto, 2006: 145). Metode Dokumentasi Yaitu mencari data-data mengenai hal-hal atau variabel yang merupakan cacatan, transkip, buku, surat kabar, majalah, agenda, dan lain sebagainya (Arikunto, 2006: 124).

Dalam menganalisa data yang telah terkumpul dari hasil penelitian, penulis menggunakan analisa sebagai berikut: 1). Analisis Pendahuluan, dalam analisis ini, penulis menggunakan distribusi frekuensi sederhana untuk setiap variable yang diteliti; 2). Analisis uji hipotesis, dalam analisis ini penulis mengadakan perhitungan lebih lanjut mengenai table distribusi frekuensi yang ada dalam analisis pendahuluan dengan menggunakan rumus statistic yaitu rumus korelasi "Product Moment"; 3). Analisis lanjut, Dalam analisis ini penulis membuat 
interpretasi dari hasil yang telah diperoleh dengan cara mengkonsultasikan nilai koefesien korelasi $\left(\mathrm{r}_{\mathrm{o}}\right)$ dengan korelasi harga kritik $\mathrm{r}$ table $\left(\mathrm{r}_{1}\right)$ taraf signifikan $1 \%(0,01)$ dan $5 \%(0,05)$, sehingga akan di ketahui ada tidaknya pengaruh variabel x terhadap variabel $\mathrm{y}$.

\section{Pembahasan}

Pada bab ini peneliti akan menganalisis data yang telah terkumpul sehingga diketahui ada tidaknya pengaruh kematangan emosi terhadap sikap tasamuh mahasiswa STAIN Salatiga program studi pendidikan agama Islam semester 8 tahun akademik 2013/2014. Analisis ini diperlukan untuk mengetahui tujuan penelitian.

Untuk mengetahui ada tidaknya pengaruh antara kematangan emosi dengan sikap tasamuh mahasiswa, maka data yang diperoleh akan dianalisis statistik dan analisa kuantitatif. Dalam menganalisa data tersebut penulis menggunakan teknik product moment sebagai berikut:

\section{Analisis Deskriptif}

Analisis pendahuluan dimaksudkan untuk mengetahui kematangan emosi dan sikap tasamuh mahasiswa dengan menggunakan rumus prosentase yaitu:

$$
P=\frac{F}{N} X 100 \%
$$

Keterangan:

$$
\begin{aligned}
& \mathrm{P}=\text { Prosentase } \\
& \mathrm{F}=\text { Frekuensi }
\end{aligned}
$$


Mudarrisa: Jurnal Kajian Pendidikan Islam, Vol. 7, No. 1, Juni 2015: 59-88

$$
\mathrm{N}=\text { Jumlah responden }
$$

\section{Kematangan Emosi}

Berdasarkan data dari hasil penelitian pada bab III tentang pengaruh kematangan emosi terhadap sikap tasamuh mahasiswa STAIN Salatiga program studi pendidikan agama Islam semester 8 tahun akademik 2013/2014 diketahui rekapitulasi adalah sebagai berikut:

Untuk kategori tinggi tentang kematangan emosi antara skor 55-60 ada 14 responden.

$$
\begin{aligned}
& P=\frac{14}{45} X 100 \% \\
& P=31.11 \%
\end{aligned}
$$

Untuk kategori sedang tentang kematangan emosi antara skor 54-49 ada 24 responden:

$$
\begin{aligned}
& P=\frac{24}{45} X 100 \% \\
& P=53.33 \%
\end{aligned}
$$

Untuk kategori rendah tentang kematangan emosi antara skor 48-44 ada 7 responden:

$$
\begin{aligned}
& P=\frac{7}{45} X 100 \% \\
& P=15,56 \%
\end{aligned}
$$


Untuk lebih jelas penulis sampaikan dalam bentuk tabel distribusi frekuensi tentang kematangan emosi mahasiswa STAIN Salatiga program studi pendidikan agama Islam semester 8 tahun akademik 2013/2014.

Tabel 1.1

Rekapitulasi kematangan emosi mahasiswa STAIN Salatiga program studi pendidikan agama Islam semester 8 tahun akademik 2013/2014

\begin{tabular}{|c|c|c|c|c|}
\hline NO & KATEGORI & TERVAL & FREKUENSI & PROSENTASE \\
\hline 1 & Tinggi & $55-60$ & 14 & $31.11 \%$ \\
\hline 2 & Sedang & $49-54$ & 24 & $53.33 \%$ \\
\hline 3 & Rendah & $44-48$ & 7 & $15.56 \%$ \\
\hline \multicolumn{2}{|c|}{ Jumlah } & & 45 & $100 \%$ \\
\hline
\end{tabular}

Dari perhitungan prosentase tersebut dapat disimpulkan bahwa kematangan emosi yang tinggi sebesar $31.11 \%$, yang sedang sebesar $53.33 \%$ dan yang rendah sebesar 15.56\%. Sehingga dengan demikian, kematangan emosi mahasiswa STAIN Salatiga Program studi pendidikan agama Islam semester 8 tahun akademik 2013/2014, tergolong dalam kategori sedang yaitu sebesar 53.33\%.

\section{Sikap Tasamuh}

Berdasarkan data dari hasil penelitian pada bab III tentang sikap tasamuh mahasiswa STAIN Salatiga Program studi pendidikan agama Islam semester 8 tahun akademik 2013/ 2014 diketahui rekapitulasi sebagai berikut: 
Mudarrisa: Jurnal Kajian Pendidikan Islam, Vol. 7, No. 1, Juni 2015: 59-88

Untuk kategori tinggi tentang sikap tasamuh antara skor 55-60 ada 22 responden.

$$
\begin{aligned}
& P=\frac{22}{45} X 100 \% \\
& P=48.89 \%
\end{aligned}
$$

Untuk kategori sedang sikap tasamuh antara skor 54-49 ada 18 responden:

$$
\begin{aligned}
& P=\frac{18}{45} X 100 \% \\
& P=40 \%
\end{aligned}
$$

Untuk kategori rendah tentang sikap tasamuh antara antara 48-43 ada 5 responden:

$$
\begin{aligned}
& P=\frac{5}{45} X 100 \% \\
& P=11.11 \%
\end{aligned}
$$

Untuk lebih jelas penulis sampaikan dalam bentuk tabel distribusi frekuensi tentang sikap tasamuh.

Tabel 2.1

Rekapitulasi Sikap tasamuh

\begin{tabular}{|r|c|c|c|c|}
\hline \multicolumn{1}{|c|}{ NO } & KATEGORI & TERVAL & FREKUENSI & PROSENTASE \\
\hline 1. & Tinggi & $55-60$ & 22 & $48.89 \%$ \\
\hline 2. & Sedang & $49-54$ & 18 & $40 \%$ \\
\hline 3. & Rendah & $43-48$ & 5 & $11.11 \%$ \\
\hline & Jumlah & & 45 & $100 \%$ \\
\hline
\end{tabular}


Dari perhitungan prosentase tersebut dapat disimpulkan bahwa sikap tasamuh yang tinggi sebesar $48.89 \%$, yang sedang sebesar $40 \%$ dan yang rendah sebesar $11.11 \%$. Sehingga dengan demikian, sikap tasamuh mahasiswa STAIN Salatiga Program studi pendidikan agama Islam semester 8 tahun akademik 2013/2014 tergolong dalam kategori tinggi yaitu sebesar $48.89 \%$.

\section{Pengujian Hipotesis}

Analisis uji hipotesis digunakan untuk menganalisis diterima tidaknya hipotesis yang diajukan dalam skripsi ini, tentang pengaruh kematangan emosi terhadap sikap tasamuh mahasiswa STAIN Salatiga Program studi pendidikan agama Islam semester 8 tahun akademik 2013/2014. Maka dibuktikan dengan mencari nilai koefisian antara variabel kematangan emosi (X) dengan sikap tasamuh mahasiswa (Y).

Adapun untuk mencari nilai koefisien tersebut, maka penulis menempuh langkah-langkah sebagai berikut:

Tabel 3.1

Tabel Kerja Untuk Mencari Korelasi Antara Variabel Kematangan Emosi (X) Dan Variabel Sikap Tasamuh (Y)

\begin{tabular}{|c|c|c|c|c|c|}
\hline NO & $\mathrm{X}$ & $\mathrm{Y}$ & $\mathrm{X}^{2}$ & $\mathrm{Y}^{2}$ & $\mathrm{X} . \mathrm{Y}$ \\
\hline 1 & 52 & 48 & 2704 & 2304 & 2496 \\
\hline 2 & 55 & 55 & 3025 & 3025 & 3025 \\
\hline 3 & 53 & 53 & 2809 & 2809 & 2809 \\
\hline 4 & 51 & 48 & 2601 & 2304 & 2448 \\
\hline
\end{tabular}


Mudarrisa: Jurnal Kajian Pendidikan Islam, Vol. 7, No. 1, Juni 2015: 59-88

\begin{tabular}{|c|c|c|c|c|c|}
\hline 5 & 60 & 60 & 3600 & 3600 & 3600 \\
\hline 6 & 51 & 45 & 2601 & 2025 & 2295 \\
\hline 7 & 57 & 58 & 3249 & 3364 & 3306 \\
\hline 8 & 53 & 60 & 2809 & 3600 & 3180 \\
\hline 9 & 46 & 50 & 2116 & 2500 & 2300 \\
\hline 10 & 52 & 48 & 2704 & 2304 & 2496 \\
\hline 11 & 48 & 56 & 2304 & 3136 & 2688 \\
\hline 12 & 45 & 55 & 2025 & 3025 & 2475 \\
\hline 13 & 53 & 57 & 2809 & 3249 & 3021 \\
\hline 14 & 49 & 50 & 2401 & 2500 & 2450 \\
\hline 15 & 57 & 55 & 3249 & 3025 & 3135 \\
\hline 16 & 46 & 50 & 2116 & 2500 & 2300 \\
\hline 17 & 58 & 60 & 3364 & 3600 & 3480 \\
\hline 18 & 51 & 56 & 2601 & 3136 & 2856 \\
\hline 19 & 58 & 57 & 3364 & 3249 & 3306 \\
\hline 20 & 59 & 60 & 3481 & 3600 & 3540 \\
\hline 21 & 47 & 53 & 2209 & 2809 & 2491 \\
\hline 22 & 56 & 56 & 3136 & 3136 & 3136 \\
\hline 23 & 56 & 56 & 3136 & 3136 & 3136 \\
\hline 24 & 57 & 55 & 3249 & 3025 & 3135 \\
\hline 25 & 53 & 56 & 2809 & 3136 & 2968 \\
\hline 26 & 54 & 51 & 2916 & 2601 & 2754 \\
\hline 27 & 53 & 58 & 2809 & 3364 & 3074 \\
\hline 28 & 44 & 43 & 1936 & 1849 & 1892 \\
\hline 29 & 50 & 52 & 2500 & 2704 & 2600 \\
\hline 30 & 53 & 58 & 2809 & 3364 & 3248 \\
\hline 31 & 55 & 51 & 3025 & 2601 & 2805 \\
\hline 32 & 54 & 60 & 2916 & 3600 & 3240 \\
\hline 33 & 56 & 54 & 3136 & 2916 & 3024 \\
\hline 34 & 50 & 56 & 2500 & 3136 & 2800 \\
\hline 35 & 51 & 54 & 2601 & 2916 & 2754 \\
\hline 36 & 52 & 58 & 2704 & 3364 & 3016 \\
\hline
\end{tabular}




\begin{tabular}{|c|c|c|c|c|c|}
\hline 37 & 56 & 53 & 3136 & 3481 & 2968 \\
\hline 38 & 50 & 53 & 2500 & 2809 & 2650 \\
\hline 39 & 52 & 56 & 2704 & 3136 & 2912 \\
\hline 40 & 51 & 54 & 2601 & 2916 & 2754 \\
\hline 41 & 60 & 53 & 3600 & 2809 & 3180 \\
\hline 42 & 52 & 51 & 2704 & 2601 & 2652 \\
\hline 43 & 53 & 54 & 2809 & 3136 & 2862 \\
\hline 44 & 48 & 51 & 2304 & 2601 & 2448 \\
\hline 45 & 51 & 53 & 2601 & 2809 & 2703 \\
\hline$\sum$ & 2368 & 2430 & 125282 & 131918 & 128234 \\
\hline
\end{tabular}

Setelah diketahui masing-masing jumlahnya, maka dapat dimasukan rumus product moment, yang meliputi:

$$
\begin{array}{llllll}
\Sigma \mathrm{x} & : 2368 & \Sigma \mathrm{x}^{2} & : 125282 & \Sigma \mathrm{xy} & : 128234 \\
\Sigma \mathrm{y} & : 2430 & \Sigma \mathrm{y}^{2} & : 131918 & \mathrm{~N} & : 45
\end{array}
$$

Dalam melakukan analisis tentang pengaruh kematangan emosi terhadap sikap tasamuh mahasiswa STAIN Salatiga program studi agama Islam semester 8 tahun akademik 2013/2014. Peneliti menggunakan rumus product moment. Dan dalam perhitungannya diperoleh $r_{x y}=0,528$.

\section{Pembahasan Hasil Uji Hipotesis}

Setelah data berhasil diuji dengan menggunakan product moment. Jadi rhitung 0,528, selanjutnya dibandingkan dengan harga $\mathrm{r}$ tabel. Dengan N 45, pada taraf signifikansi 5\% 0,294 r hitungnya adalah 0,528 yang berarti $r$ hitung $>r$ tabel, sedangkan taraf signifikan untuk $1 \%$ 0,380, $r$ hitung adalah 0,528 berarti $r$ hitung $>\mathrm{r}$ tabel. Ketentuan 
(Sugiyono, 2008: 190), bila $\boldsymbol{r}$ hitung lebih kecil dari $\boldsymbol{r}$ tabel, maka Ho diterima, dan Ha ditolak. Tetapi sebaliknya bila $r$ hitung lebih besar dari r tabel (rh > rt) maka Ha “diterima”. Dari hasil tampak bahwa $r$ hitung lebih besar dari r tabel maka Ha diterima, dengan demikian hasil dari 0,528 tersebut adalah signifikan. Terdapat hubungan yang positif dan signifikan antara kematangan emosi dengan sikap tasamuh Mahasiswa STAIN Program Studi Pendidikan Agama Islam semester 8 Tahun Akademik 2013/2014.

Oleh karena itu, penelitian ini telah membuktikan bahwa ada pengaruh yang signifikan antara kematangan emosi dengan sikap tasamuh Mahasiswa STAIN Salatiga program studi Pendidikan Agama Islam semester 8 tahun Akademik 2013/2014.

\section{Simpulan}

Berdasarkan hasil penelitian pada bab III dan IV, dapat diambil kesimpulan sebagai jawaban untuk mengetahui tujuan penelitian sebelumnya yakni: untuk mengetahui pengaruh kematangan emosi (X), dengan sikap tasamuh (Y) mahasiswa STAIN Salatiga program studi pendidikan agama Islam semester 8 tahun akademik 2013/2014, maka setelah diadakan perhitungan menunjukkan:

Bahwa kematangan emosi mahasiswa STAIN Salatiga program studi pendidikan agama Islam semester 8 tahun akademik 2013/2014. Dalam kategori tinggi, sedang, dan rendah dari 45 responden dapat dikelompokkan sebagai berikut: a). Tergolong kategori tinggi ada 14 mahasiswa atau $31,11 \%$; b). Tergolong kategori sedang ada 24 
mahasiswa atau 53,33\%; c). Tergolong kategori rendah ada 7 mahasiswa atau $15,56 \%$. Sehingga dengan demikian, kematangan emosi mahasiswa STAIN Salatiga Program studi Pendidikan Agama Islam semester 8 tahun akademik 2013/2014, tergolong dalam kategori sedang yaitu sebesar $53.33 \%$.

Bahwa sikap tasamuh mahasiswa STAIN Salatiga program studi pendidikan agama Islam semester 8 tahun akademik 2013/2014 dalam kategori tinggi, sedang dan rendah dari 45 responden adalah: a). Tergolong kategori tinggi ada 22 mahasiswa atau 48,89\%; b). Tergolong kategori sedang ada 18 mahasiswa atau 40\%; c).Tergolong kategori rendah ada 5 mahasiswa atau 11,11\%. Sehingga dengan demikian, sikap tasamuh mahasiswa STAIN Salatiga Program studi pendidikan Agama Islam semester 8 tahun akademik 2013/2014 tergolong dalam kategori tinggi yaitu sebesar $48.89 \%$.

Dari hasil olah data secara statistik menyatakan bahwa ada pengaruh yang signifikan antara kematangan emosi dengan sikap tasamuh mahasiswa Stain Salatiga pogram studi Pendidikan Agama Islam tahun akademik 2013/2014. Hal ini terlihat dari hasil perhitungan $\mathrm{N}$ 45, pada taraf signifikansi 5\% 0,294 $r$ hitungnya adalah 0,528 yang berarti $r$ hitung > $r$ tabel, sedangkan taraf signifikan untuk 1\% 0,380 $r$ hitung adalah 0,528 berarti $\mathrm{r}$ hitung > r tabel. Ketentuan (Sugiyono, 2008: 190), bila r hitung lebih kecil dari r tabel, maka Ho diterima, dan Ha ditolak. Tetapi sebaliknya bila $r$ hitung lebih besar dari r tabel (rh > rt ) maka Ha "diterima”. Dari hasil tampak bahwa $r$ hitung lebih 
Mudarrisa: Jurnal Kajian Pendidikan Islam, Vol. 7, No. 1, Juni 2015: 59-88

besar dari $\mathrm{r}$ tabel maka Ha diterima, dengan demikian hasil dari 0,528 tersebut adalah signifikan.

\section{Daftar Pustaka}

Ahmadi, Abu \& Sholeh, Munawar. 2005. Psikologi Perkembangan. Jakarta: Rineka Cipta.

Ahmadi , Abu. 1999. Psikologi Sosial. Jakarta: Rineka Cipta.

Al-Asqalany, Ibn Hajar. 1417H/ 1996 M. Fathkhul Bary, (Cet. I. Jilid 1. Madinah al-Munawarah.

Ambarsari, Aprilia. 2005. Hubungan Kematangan Emosi Dengan Kecemasan Menghadapi Perkawinan Pada Remaja Akhir. Skripsi. Tidak diterbitkan. Salatiga: Fakultas Psikologi Universitas Kristen Satya Wacana.

Arikunto, Suharsimi. 2006. Prosedur Penelitian Suatu Pendekatan Praktek edisi revisi v. Jakarta: PT Rineka Cipta.

Arikunto, Suharsimi . 2010. Prosedur Penelitian Suatu Pendekatan Praktek cetakan ke 14. Jakarta: PT Rineka Cipta.

Asih Yuli, Gusti. \& Shinta Pratiwi, Margaretha. 2010. Perilaku Prososial Ditinjau Dari Empati Dan Kematangan Emosi, (Online). Volume 1, NO. 1, (http://www.Jurnal Psikologi Unervisitas Muria Kudus.ac.id, diakses 5 juli 2014 pukul 14.00 WIB).

Chaplin. J.P., Penerjemah Kartini Kartono. 2008. Kamus Lengkap Psikologi. Jakarta: Raja Grafindo Persada.

Dariyo, Agoes. 2004. Psikologi Perkembangan Dewasa Muda. Jakarta: PT Grasindo.

Departemen Agama RI. 2009. AL-Quran Dan Terjemahannya. Bandung: PT Sigma.

Djaali, H. 2013. Psikologi Pendidikan. Jakarta: Bumiaksara.

Hadi, Sutrisno. 2000. Metodologi Research jilid 1, Yogyakarta : Andi Offset. 
Hadi, Sutrisno. 2002. Metodologi Research. Yogyakarta : Andi Offset.

Hartati, Netty. Nihayah ,Zuhrotun. Shaleh, Abdul Rahman. \& Mujib, Abdul. 2005. Islam dan Psikologi. Jakarta: Raja Grafindo, Persada.

Hude ,darwis. 2006. Emosi penjelajahan Religion-Psikologis Tentang Emosi manusia di dalam Al-Quran. Jakarta:Erlangga.

Hurlock, Elizabeth B. 2006.Psikologi Perkebangan suatu pendekatan sepanjang rentang kehidupan edisi kelima. Jakarta: Erlangga.

Kawatja, Soegarda Poerba. 1982. Ensiklopedi Pendidikan. Jakarta: Gunung Agung.

Masduqi, Irwan. 2011. Berislam Secara toleran: Teologi Kerukunan Umat Beragama. Bandung: PT Mizan Pustaka Anggota IKAPI.

Minkhatun. 2005. Pengaruh Mendengarkan Acara Mimbar Islam DI RRI Semarang Terhadap Perilaku Tasamuh Masyrakat Kecamatan Tembalang Kota Semarang. Skripsi tidak diterbitkan. Semarang: Fakultas Dakwah Institut Agama Islam Negeri Walisongo Semarang.

Muallifah. 2009. Psycho Islamic Smart Parenting, Jogjakarta: Diva Press.

Musthofa, Yasin. 2007. EQ untuk Anak Usia Dini dalam Pendidikan Islam: Meningkatkan Perilkau Pengendalian Diri dan Rasa Empati atau Kasih Sayang pada Anak. Yogyakarta: Sketsa.

Rebert, Athur S. \& Rebert, Emily S. 2010. Kamus Psikologi. Jogjakarta. Pustaka Belajar.

Riduwan. 2010. Belajar Mudah Penelitian untuk Guru-Karyawan dan Peneliti Pemula, Bandung: Alfabeta Anggota IKAPI.

Sarwano, Sarlito. W., \& Meimarno, Eko A., 2009. Psikologi Sosial. Jakarta: Salemba Humanika.

Sugiyono. 2008. Metode Penelitian Kuantitatif, Kualitatif, Dan, $R \& D$. Bandung: Alfabeta.

Sugiyono. 2010. Statistika Untuk Penelitian. Bandung: Alfabeta. 
Mudarrisa: Jurnal Kajian Pendidikan Islam, Vol. 7, No. 1, Juni 2015: 59-88

Tatapangarsa, Humaidi. 1980. Akhlaq Mulia. Surabaya: Bina Ilmu Offset.

Umar. Muin. 1991. Komunitas Religius Sosial dan Politik dalam AlQur'an. Yogyakarta. Mitragama Media.

Walgito, Bimo .1990. Psikologi Sosial (Suatu Pengantar). Yogyakarta: Andi Offset.

Walgito, Bimo. 2002. Bimbingan dan Konseling Perkawinan. Yogyakarta: Andi Offset.

Yusuf, Syamsu. 2011. Psikologi Perkembangan Anak dan Remaja. Bandung: PT Remaja Rosdakarya. 